\title{
MENAKAR DAMPAK SUKU BUNGA, NILAI TUKAR, DAN INFLASI TERHADAP PERMINTAAN KREDIT KONSUMSI
}

\author{
Wardihan Sabar \\ Universitas Islam Negeri Alauddin Makassar \\ wardihan.sabar@uin-alauddin.ac.id \\ Kuslin \\ Universitas Islam Negeri Alauddin Makassar \\ kuslin@gmail.com
}

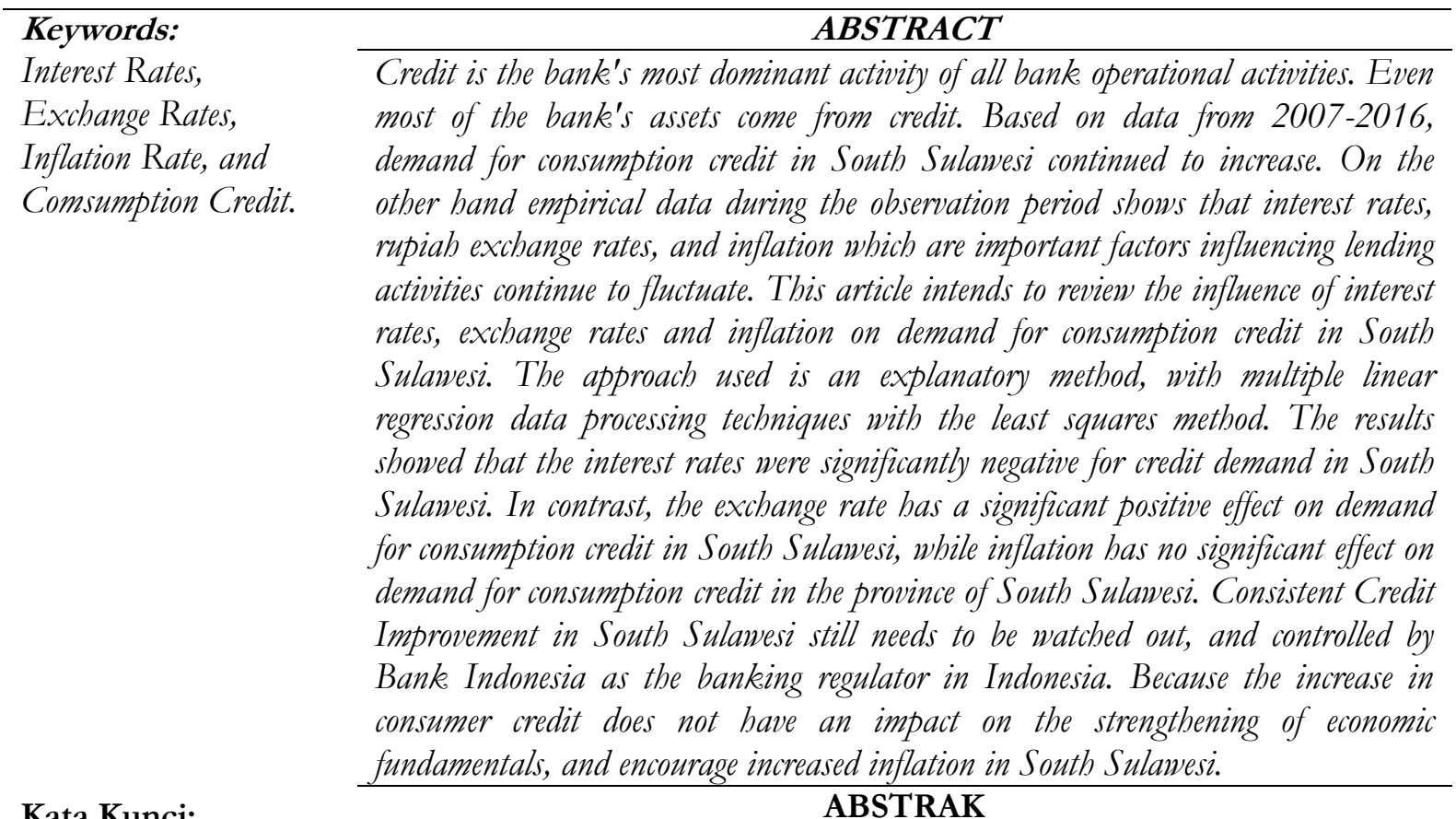

Kata Kunci:

Suku Bunga, Nilai

Tukar Rupiah, Inflasi, dan Kredit Konsumsi
Kredit merupakan aktivitas bank yang paling dominan dari seluruh kegiatan aktivitas operasional bank. Bahkan sebagian besar aset bank berasal dari kredit. Bedasarkan data tahun 2007-2016 permintaan kredit konsumsi di Sulawesi Selatan terus mengalami peningkatan. Disisi lain data empirik selama periode pengamatan menunjukan bahwa suku bunga, nilai tukar rupiah, dan inflasi yang menjadi faktor penting yang mempengaruhi aktifitas penyaluran kredit terus berfluktuasi. Artikel ini bermaksud mengulas pengaruh suku bunga, nilai tukar dan inflasi terhadap permintaan kredit konsumsi di sulawesi selatan. Pendekatan yang digunakan adalah pendekatan eksplanatori, dengan teknik pengolahan data regresi linear berganda dengan metode kuadrat terkecil. Hasil penelitian menunjukkan bahwa suku bunga signifikan negatif terhadap permintaan kredit di Sulawesi Selatan. Lain halnya dengan nilai tukar berpengaruh signifikan positif terhadap permintaan kredit konsumsi di sulawesi selatan, sedangkan inflasi tidak berpengaruh signifikan terhadap permintaan kredit konsumsi di provinsi Sulawesi selatan. Peningkatan kredit konsmtif di Sulawesi Selatan tetap perlu diwaspadai, dan dikendalikan oleh Bank Indonesia selaku regulator perbankan di Indonesia. Sebab kenaikan kredit konsumtif tidak memberikan dampak pada penguatan fundamental perekonomian, dan mendorong pengikatan inflasi di sulawesi Selatan. 


\section{PENDAHULUAN}

Kegiatan menyalurkan kredit kepada masyarakat selain merupakan pendapatan utama bank, kegiatan ini juga mengandung resiko yang sangat tinggi. Jika penyaluran kredit yang dilakukan oleh suatu bank tinggi dengan disertai kolektibilitas yang baik, maka bank tersebut tidak akan menemui masalah. Akan tetapi jika kolektibilitas kredit yang dilakukan oleh bank tidak baik, maka bank tersebut akan mengalami kualitas kredit yang jelek, dimana jumlah non performing loan yaitu kredit kurang lancer, kredit diragukan maupun kredit macet tinggi. Jika hal ini terjadi maka pendapatan maupun laba perusahaan tidak akan meningkat bahkan kemungkinan akan mengalami penurunan. Hal ini tentu saja akan berpengaruh terhadap kinerja bank sekaligus kepercayaan masyarakat. (Thahir: 2002).

Sebagaimana umumnya negara berkembang, sumber utama pembiayaan investasi di Indonesia masih didominasi oleh penyaluran kredit perbankan. Lambatnya penyalur kredit perbankan di Indonesia setelah krisis tahun 1997 dituding sebagai salah satu penyebab lambatnya pemulihan ekonomi Indonesia. Walaupun sempat terjadi penurunan tajam terhadap alokasi kredit perbankan, namun pada tahun 2001 secara perlahan kredit mulai menunjukkan peningkatan. Hal ini seiring dengan meningkatnya portofolio kredit sejak tahun 2002 (Laporan Tahunan Bank Indonesia, 2000-2005).

Meskipun penyaluran kredit memegang peranan penting bagi pertumbuhan ekonomi negara, namun kredit yang disalurkan oleh perbankan belum optimal. hal ini dapat terlihat dari Loan to Deposit Ratio (LDR Bank Umum periode 2006-2010 yang masih berkisar pada angka 61,56\% -75,21\% (statistik Perbankan Indonesia), masih berada di bawah harapan Bank Indonesia. Berdasar ketentuan Bank Indonesia, angka LDR seharusnya berada disekitar 85\%110\% (Manurung, Rahardja, 2004).

Berdasarkan laporan publikasi Bank Indonesia Tahun 2007-2016, diketahui bahwa permintaan kredit konsumsi di Sulawesi Selatan terus mengalami peningkatan pada setiap tahunnya, dimulai pada tahun 2007 jumlah permintaan kredit konsumsi di Sulawesi Selatan sebesar Rp. 99.349.080.000,- kemudian di tahun berikutnya terus mengalami peningkatan yang signifikan hingga pada tahun 2016 jumlah permintaan kredit konsumsi tumbuh sebesar Rp. 497.480.500.000,- Hal ini secara jelas menunjukkan bahwa pertumbuhan kredit konsumsi tumbuh sangat tinggi dalam beberapa tahun terakhir.

Dari keseluruhan kegiatan perekonomian, kegiatan konsumsi tetap sebagai mesin penggerak perekonomian. Permintaan barang dan jasa yang merupakan kebutuhan masyarakat baik kebutuhan pokok (makanan, pakaian, rumah) maupun kebutuhan barang mewah (rumah mewah, mobil, elektronik) ataupun jasa-jasa ekonomi lainnya seperti transportasi, hotel, restoran, pesta dan lain sebagainya. Dalam memenuhi kebutuhan masyarakat yang tidak terbatas ini, tentu dibutuhkan biaya yang tinggi. Untuk barang-barang yang nilainya tinggi dan tidak bersifat pokok seperti rumah mewah, kendaraan, barang-barang elektronik dan barangbarang lainnya yang memungkinkan mereka beli dengan sistem kredit yaitu dengan membayar cicilan setiap jangka waktu yang telah ditetapkan.

Kunci dari pengeluaran konsumsi adalah pendapatan. Semakin besar pendapatan seseorang maka semakin besar pula pengeluaran untuk melakukan konsumsi. Pengeluaran dapat naik saat pendapatan naik dan bahkan pengeluran konsumsi lebih cepat naiknya dibandingkan pendapatan itu sendiri, sebaliknya apabila pendapatan turun maka konsumsi akan sulit untuk turun (Miraza, 2006).

Saat perekonomian memasuki tahap ekspansi dari suatu siklus bisnis dan juga meningkatkan real Gross Domestic Product (GDP) maka akan meningkatkan transaksi keuangan yang akan mengakibatkan permintaan terhadap uang juga akan meningkat dimana supplus interest rate maka semakin besar pula keinginan untuk berbelanja, karena tidak menariknya timbal balik yang dihasilkan oleh investasi (Subagyo dkk, 2002). Sementar Muliaman (2004) 
meneliti tentang permintaan dan penawaran kredit konsumsi rumah tangga di Indonesia, hasil penelitian menunjukan bahwa suku bunga berpengaruh negatif terhadap permintaan kredit konsumsi.

Bank Indonesia mulai memberikan signal penurunan tingkat bunga secara bertahap. Hal ini dilakukan melalui penurunan tingkat bunga instrument moneter yang salah satunya adalah Sertifikat Bank Indonesia (SBI). Turunnya SBI diharapkan dapat semakin mendorong aktifitas perekonomian melalui penurunan suku bunga kredit perbankan. Suku bunga kredit yang ada pada saat ini dianggap beberapa kalangan baik dari pelaku bisnis maupun pakar ekonomi belum optimal.

Nilai tukar dapat menjadi salah satu faktor yang diduga berpengaruh terhadap volume kredit konsumsi, ketika nilai tukar mata uang domestik melemah maka harga barang impor akan meningkat, dengan demikian harga barang domestik mengalami peningkatan. Menurut mashab klasik bahwa apabila kurs mengalami peningkatan, secara tidak langsung kredit konsumsi juga meningkat akibat dari peningkatan pendapatan masyarakat. Penelitian yang dilakukan oleh junaidi (2006), diperoleh hasil bahwa nilai tukar rupiah terhadap dollar berpengaruh positif terhadap permintaan kredit.

Inflasi dapat menciptakan suatu lingkungan yang tidak stabil bagi keputusan ekonomi. Jika sekiranya konsumen memperkirakan bahwa tingkat inflasi di masa mendatang akan naik, maka akan mendorong mereka untuk melakukan pembelian barang-barang dan jasa secara besar-besaran pada saat sekarang ketimbang mereka menunggu dimana tingkat harga sudah meningkat lagi. Begitu pula halnya dengan bank, atau lembaga peminjaman lainnya, jika sekiranya mereka menduga bahwa tingkat inflasi akan naik dimasa mendatang, maka mereka akan mengenakan tingkat bunga yang tinggi atas pinjaman yang diberikan sebagai langkah proteksi dalam menghadapi penurunan pendapatan riil.

Penelitian tentang permintaan kredit konsumsi telah banyak dilakukan, seperti Wahab (2015) di Sulawesi Selatan, Hadi (2008) di Sumatera Utara, Harefa dan Albert (2010), Tandris, Raimond, et al (2014) di Kota Manado, Hutagalung dan Nasution (2013) di Sumatera Utara, serta Pratama (2010) yang menfokuskan pada kebijakan penyaluran kredit Bank Umum di Indonesia. Artikel ini bermaksud untuk mengulas pengaruh suku bunga, nilai tukar dan inflasi terhadap permintaan kredit konsumsi di Sulawesi Selatan. Artikel ini juga bermaksud untuk memperbandingkan dengan hasil-hasil penelitian terdahulu, sehingga diharapkan dapat memperkaya khasanah keilmuan di bidang ekonomi, keuangan dan perbankan.

\section{LANDASAN TEORI}

Kaidah permintaan dinyatakan dalam cara paling sederhana sebagi berikut: pertama, pada harga tinggi lebih sedikit barang yang akan diminta ketimbang pada harga rendah, asalkan hal-hal lain sama. Kedua, pada harga rendah lebih banyak barang yang akan diminta ketimbang pada harga tinggi, asalkan hal-hal lain sama. Jadi, kaidah permintaan mengatakan bahwa kuantitas yang diminta untuk suatu barang berhubungan terbalik dengan harga barang tersebut, asalkan hal-hal lain sama pada setiap tingkat harga (Miller dan Meiners, 2000).

Permintaan (demand) adalah sejumlah barang atau jasa yang diminta oleh konsumen pada beberapa tingkat harga pada suatu waktu tertentu dan pada tempat atau pasar tertentu (Palutturi, 2005). Menurut (Lipsey 1990), demand adalah jumlah yang diminta merupakan jumlah yang diinginkan. Permintaan suatu barang di pasar akan terjadi apabila konsumen mempunyai keinginan dan kemampuan untuk membeli. Pada tahap ini konsumen hanya memiliki keinginan atau kemampuan saja, maka permintaan suatu barang belum terjadi. Kedua syarat dari keinginan dan kemampuan harus ada untuk terjadinya permintaan (Turner cit Yassir Muhammad, 2014). 
Seseorang dalam usaha memenuhi kebutuhannya pertama kali yang akan dilakukan adalah pemilihan atas berbagai barang dan jasa yang dibutuhkan. Selain itu juga dilihat apakah harganya sesuai dengan kemampuan yang dimiliki. Jika harganya tidak sesuai, maka ia akan memilih barang dan jasa yang sesuai dengan kemampuan yang dimilikinya. Perilaku tersebut sesuai dengan hukum permintaan (Samuelson dan Nordhaus 1996) yang mengatakan bahwa bila harga suatu barang atau jasa naik, maka jumlah barang dan jasa yang diminta konsumen akan mengalami penurunan, dan sebaliknya bila harga dari suatu barang atau jasa turun, maka jumlah barang dan jasa yang diminta konsumen akan mengalami kenaikan (ceteris paribus). Fungsi permintaan menunjukan hubungan antara kuantitas suatu barang yang diminta dengan semua faktor yang mempengaruhinya misalnya harga, pendapatan, selera dan harapan-harapan untuk masa mendatang.

Hubungan antara harga satuan komoditas (barang dan jasa) yang mau dibayar pembeli dengan jumlah komoditas tersebut dapat disusun dalam suatu table yaitu daftar permintaan. Data yang diperoleh dari daftar permintaan tersebut dapat digunakan pula untuk menggambarkan sifat hubungan antara harga suatu komoditas dengan jumlah komoditas tersebut yang diminta dalam suatu kurva permintaan. Perlu dibedakan antara permintaan dan jumlah barang yang diminta. Permintaan adalah keseluruhan daripada kurva permintaan sedangkan jumlah barang yang diminta adalah banyaknya permintaan pada suatu tingkat harga tertentu (Sugiarto, 2005). Faktor-faktor yang mempengaruhi permintaan yaitu banyaknya barang pengganti yang tersedia, jumlah penggunaan barang tersebut, besarnya persentase pendapatan yang dibelanjakan dan jangka waktu dimana permintaan itu dianalisis (Tri kunawangsih \& Antyo Pracoyo, 2006).

Dalam analisis tersebut, dapat di asumsikan bahwa "faktor-faktor lain tidak mengalami perubahan" atau ceteris paribus. Tetapi dengan asumsi yang dinyatakan ini tidaklah berarti bahwa kita dapat mengabaikan faktor-faktor tersebut. Setelah menganalisa hubungan antara jumlah permintaan dan tingkat harga maka kita selanjutnya boleh mengasumsikan bahwa harga adalah tetap dan kemudian menganalisis bagian permintaan suatu barang dipengaruhi oleh faktorfaktor lainnya. Dengan demikian dapat diketahui bahwa permintaan terhadap suatu barang akan berubah apabila citra rasa atau pendapatan atau harga barang- barang lain juga mengalami perubahan.

Khusus untuk permintaan kredit konsumsi dapat diproxy dalam teori permintaan uang (Money Demand Theory). Sebagamana pendapat ahli mengenai permintaan uang tentu memiliki kajian tersendiri yang dapat dijadikan acuan dalam melihat keterkaitan antar faktor-faktor penentu permintaan uang dalam suatu Negara, atau wilayah.

Salah satu ahli yang mengulas tentang permintaan uang adalah Keynes dalam bukunya The General Theoryof Employment, Interest and Money (Budiono cit Sidiq, 2005). Pada teori ini Keynes mengemukakan sesuatu yang berbeda dengan teori permintaan uang tradisi klasik. Perbedaan tersebut terletak pada penekanan oleh Keynes pada fungsi uang yang lain yaitu sebagai penyimpan kekayaan (store of value) dan bukan hanya sebagai alat transaksi saja (means of Exchange) saja. Didalam teorinya Keynes membagi permintaan uang atas tiga motif yaitu untuk transaksi, berjaga-jaga dan untuk spekulasi.

Permintaan uang untuk transaksi dan berjaga-jaga tergantung pada tingkat pendapatan. Semakin besar pendapatan seseorang atau masyarakat semakin besar permintaan uang untuk tujuan transaksi. Keynes juga berpendapat permintaan uang untuk berjaga-jaga tergantung pada pendapatan berkaitan dengan cadangan untuk sesuatu hal yang tak terduga. Semakin besar pendapatan seseorang atau masyarakat maka semakin besar pula cadangan uang tunai untuk hal-hal yang tak terduga. Permintaan uang untuk tujuan spekulasi hanya dikenal oleh pengikut Keynes sedang kaum Klasik tidak sependapat tentang hal tersebut (Sidiq, 2005).

Dalam permintaan uang untuk spekulasi ini tergantung pada tingkat bunga. Semakin tinggi tingkat suku bunga semakin rendah permintaan uang tunai oleh seseorang atau 
masyarakat. Alasanya adalah semakin tinggi tingkat bunga, maka semakin besar ongkos memegang uang tunai sehingga seseorang atau masyarakat lebih baik membeli obligasi. Sebaliknya semakin rendah tingkat bunga maka semakin rendah ongkos memegang uang tunai dan semakin besar seseorang atau masyarakat menyimpan uang tunai. Berdasarkan pada penjelasan diatas, permintaan uang total menurut Keynes adalah sebagai berikut:

$$
(M / P) d=f(Y)+k(r)
$$

Artinya permintaan uang riil tergantung pada tingkat pendapatan $(Y)$ yaitu untuk transaksi dan berjaga-jaga dan tergantung pada tingkat bunga $(r)$ untuk tujuan spekulasi.

Menurut pandangan Friedman permintaan uang ditentukan oleh faktor-faktor berikut: tingkat harga, suku bunga obligasi, suku bunga 'equities', modal fisik dan kekayaan (Sukirno cit Sidiq, 2005). Mengenai peranan harga dalam mementukan permintaan uang, Friedman berpendapat dikarenakan memegang uang adalah salah satu cara untuk menyimpan kekayaan. Cara-cara yang lain adalah menyimpan dalam bentuk harta keuangan (financial asset) seperti obligasi, deposito dan saham, menyimpan dalam harta tetap (tanah dan rumah) dan kekayaan manusiawi. Berdasarkan pada faktor-faktor yang mempengaruhi permintaan uang seperti diatas, teori permintaan yang didasarkan pada teori kuntitas modern yang dikembangkan oleh Friedman dapat dinyatakan dalam persamaan berikut:

$$
M D=f(P, r, r F C, Y)
$$

Dimana MD permintaan uang nominal, $\mathrm{P}$ adalah tingkat harga, $\mathrm{r}$ adalah suku bunga, $\mathrm{rFC}$ adalah tingkat pengembalian modal dari modal fisik dan $\mathrm{Y}$ adalah pendapatan dan kekayaan. Apabila dipertimbangkan pula pandangan Friedman mengenai permintaan uang riil, maka persamaan permintaan uang dinyatakan:

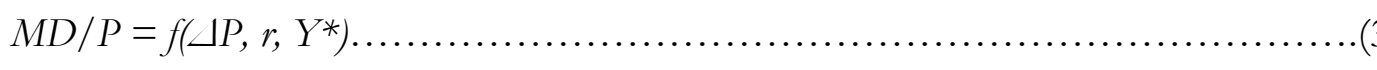

Dimana MD/P adalah permintaan uang riil, $\Delta P$ adalah tingkat kenaikan harga, $\mathrm{r}$ adalah tingkat bunga dan $\mathrm{Y}^{*}$ adalah nilai pendapatan dan kekayaan riil. Model permintaan uang riil diatas masih dalam bentuk umum, Secara spesifik, bentuk fungsi diatas masih sangat dipengaruhi oleh faktor-faktor lain seperti perkembangan institusi keuangan dan kelembagaan lainnya yang terkait didalam perekonomian dan juga oleh kebijkan-kebijakan yang dilakukan oleh pemerintah.

Kunci dari pengeluaran konsumsi adalah pendapatan. Semakin besar pendapatan maka semakin besar pengeluaran konsumsi. Pengeluaran dapat naik saat pendapatan naik dan bahkan pengeluaran konsumsi lebih cepat naiknya dibandingkan pendapatan itu sendiri, sebaliknya apabila pendapatan turun maka konsumsi akan sulit untuk turun. Namun, ada upaya untuk menurunkan pengeluaran konsumsi walaupun pendapatan sudah turun. Dengan kata lain, turunya pengeluaran konsumsi lebih lambat dari pendapatan (Miraza, 2006). Berbeda halnya dengan teori yang dinyatakan oleh (John Maynard Keynes 1969) dalam General Theory nya membuat fungsi konsumsi sebagai pusat fluktuasi ekonominya dan teori itu telah memainkan peran penting dalam analisis makro ekonomi sampai saat ini. Keynes membuat dugaan tentang fungsi ekonomi berdasarkan intropeksi dan observasi kasual.

Dugaan pertama keynes adalah bahwa kecendrungan mengkonsumsi marginal adalah antara nol dan satu. Ia menulis bahwa "hukum psikologis fundamental", dengan apa kita dinisbikan untuk tergantung pada keyakinan yang besar adalah bahwa manusia diatur, sebagai peraturan atau berdasarkan rata-rata, untuk meningkatkan konsumsi ketika pendapatan mereka naik, tetapi tidak sebanyak kenaikan dalam pendapatan mereka”. Dugaan kedua, Keynes 
Wardihan Sabar, dan Kuslin. Menakar Dampak Suku Bunga...

menyatakan bahwa rasio konsumsi terhadap pendapatan yang disebut kecendrungan mengkonsumsi rata-rata turun ketika pendapatan naik. Ia percaya bahwa tabungan adalah kemewahan sehingga ia berharap orang kaya menabung proporsi yang lebih tinggi dari pendapatan mereka ketimbang si miskin. Ketiga, Keynes berpendapat bahwa pendapatan merupakan determinan yang penting dan tingkat bunga tidak memiliki peran penting. Keynes mengatakan bahwa pengaruh tingkat bunga terhadap konsumsi hanya sebatas teori. Ketiga dugaan tersebut kemudian dirumuskan menjadi fungi matematis sebagai berikut :

$$
C=a+b Y_{d}
$$

Dimana $\mathrm{C}$ : nilai konsumsi yang dilakukan oleh semua rumah tangga dalam perekonomian $A$ : konsumsi otonom, yaitu tingkat konsumsi yang tidak dipengaruhi oleh pendapatan nasional. Nilai $a>0 B$ : kecenderungan mengkonsumsi marjinal (MPC). Nilai $0<b$

Teori konsumsi yang dikemukakan oleh (James S. Duesenberry 1949), teori ini mengatakan bahwa pengeluaran konsumsi dari individu atau rumah tangga tidak bergantung pada pendapatan sekarang dari individu, tetapi pada tingkat pendapatan tertinggi yang pernah dicapai seseorang sebelumnya. Menurut (Duesenberry cit Irsanti, 2014) pengeluaran konsumsi seseorang atau rumah tangga bukanlah fungsi dari pendapatan absolut, tetapi fungsi dari posisi relatif seseorang di dalam pembagian pendapatan di dalam masyarakat. Artinya pengeluaran konsumsi individu tersebut tergantung pada pendapatanya relatif terhadap pendapatan individu lainnya di dalam masyarakat.

Dalam kaitan ini, Duesenberry menyebutkan bahwa ada dua karakteristik penting dari perilaku konsumsi rumah tangga yaitu adanya sifat saling ketergantungan diantara rumah tangga dan tidak dapat dirubah sepanjang waktu. Saling ketergantungan disini menjelaskan mengapa rumah tangga yang berpendapatan rendah cenderung memiliki $A P C$ yang lebih tinggi dari pada rumah tangga yang berpendapatan tinggi. Hal ini terjadi karena rumah tangga yang berpendapatan rendah telah terkena dengan yang disebutkan oleh Duesenberry yaitu sebagai efek demonstrasi dimana masyarakat berpendapatan rendah cenderung meniru atau mengkopi pola konsumsi dari masyarakat sekelilinya yang cenderung menaikkan pengeluaran konsumsinya.

Menurut Duesenberry seseorang atau rumah tangga akan berusaha sedemikian rupa untuk mempertahankan standar hidup atau pola konsumsi mereka, dan hal itu dilakukan dengan cara mengurangi tabungan. Rumah tangga akan memulai hidup dengan tabungan negatif (dissaving). Hal ini berarti penurunan yang terjadi di dalam pengeluaran konsumsi rumah tangga hanyalah satu penurunan yang bersifat parsial. Pengeluaran konsumsi sebagai mana yang telah dikemukakan adalah bersifat irreversible sepanjag waktu, yang berarti bahwa dengan suatu penurunan di dalam pendapatan maka pengeluaran konsumsi juga akan mengalami penurunan, namun dalam jumlah yang lebih kecil.

Lain pula halnya yang disebutkan oleh Friedman dalam bukunya yang berjudul $A$ Theory of the Consumption Function Miton Friedman (1957), mengemukakan bahwa pengeluaran konsumsi sekarang bergantung pada pendapatan sekarang dan pendapatan yang diperkirakan di masa yang akan datang. Hal ini menekankan bahwa manusia mengalami perubahan acak dan temporer dalam pendapatan mereka dari tahun ke tahun. Friedman beralasan bahwa konsumsi seharusnya terutama bergantung pada pendapatan permanen, kerena konsumen menggunakan tabungan dan pinjaman untuk melancarkan konsumsi dalam menanggapi perubahan transistoris dalam pendapatan. 


\section{AL-MASHRAFIYAH: Jurnal Ekonomi, Keuangan, dan Perbankan Syariah Volume 2, Nomor 2, Oktober 2018}

\section{METODE PENELITIAN}

Metode yang digunakan adalah metode eksplanatori. Pendekatan ini bertujuan untuk menguji suatu teori atau hipotesis guna memperkuat atau bahkan menolak teori atau hipotesis hasil penelitian yang sudah ada sebelumnya. Penelitian eksplanatori atau eksplanatif bertujuan untuk menjelaskan hubungan antara dua atau lebih gejala atau variabel (Leedy et al., 2005).

Sumber data diperoleh dari Bank Indonesia sebagai lembaga resmi mengenai pelaporan keuangan dan perbankan. Teknik yang digunakan dengan persamaan exponential function dengan multiple regression, sebagai berikut;

$$
Q d K K m s_{t}=\beta_{0} S B I_{t}^{\beta 1} N T R p_{t}{ }^{\beta 2} \operatorname{Inf}_{t}^{\beta 3 \mu t}
$$

Untuk mengestimasikan koefisien regresi, sesuai pendapat Feldstein (1988) dilakukan transformasi ke bentuk linear dengan menggunakan logaritma natural (ln) parsial ke dalam model sehingga diperoleh persamaan sebagai berikut:

$$
\operatorname{Ln} Q d K K m s_{t}=\beta_{0}+\beta_{1} \operatorname{LnSBI}+\beta_{2} \operatorname{LnNTR}_{t}+\beta_{3} \operatorname{LnInf_{t}}+\mu_{t}
$$

Dimana:

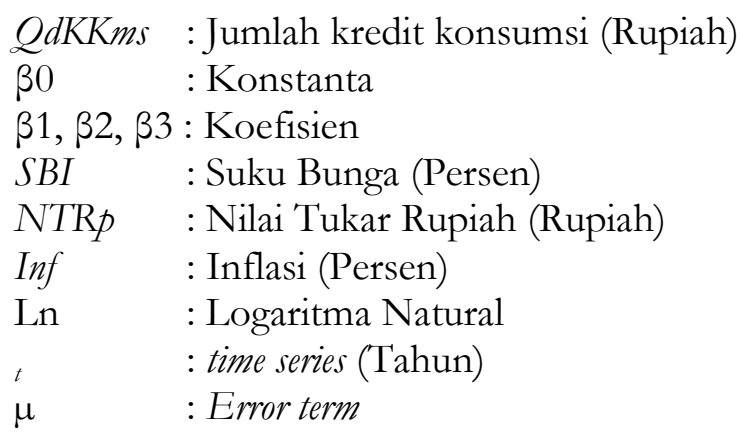

Pengukuran goodness of fit dihitung dengan adjusted $\mathrm{R}^{2}$. Menurut Gujarati and Porter cit Rahim (2012), dirumuskan sebagai berikut :

$$
\text { Adjusted } \mathrm{R}^{2}=1-\left(1-R^{2}\right) \frac{(n-1)}{(k-1)}
$$

Dimana :

$$
\begin{array}{ll}
\text { Adjusted } \mathrm{R}^{2} & : \text { koefisien determinasi yang disesuakan } \\
\mathrm{k} & : \text { jumlah variabel yang tidak termasuk intersep } \\
\mathrm{n} & : \text { jumlah sampel }
\end{array}
$$

Pengujian hipotesis terhadap koefisien regresi secara bersama-sama digunakan uji-F dengan tingkat kepercayaan tertentu, yang menurut Greene (1990) serta Gujarati and Porter (2009) dirumuskan sebagai berikut :

$$
\begin{aligned}
& F \text { bitung }=\frac{E S S /(k-1)}{R S S /(n-k)} \quad \ldots \\
& F \text { tabel }[(k-1):(n-k) ; \alpha]
\end{aligned}
$$

Dimana:

$\alpha \quad$ : tingkat signifikan 
Wardihan Sabar, dan Kuslin. Menakar Dampak Suku Bunga...

Pengujian terhadap koefisien regresi secara individu (parsial) digunakan uji t dengan tingkat kepercayaan tertentu. Menurut Greene (1990) serta Gujarati and Porter (2009) dengan rumus :

$$
\begin{aligned}
& \text { thitung }=\frac{\beta i}{S \beta i} \ldots \ldots \ldots \ldots \ldots \ldots \ldots \ldots \ldots \ldots \ldots \ldots \ldots \ldots \ldots \ldots \ldots \ldots \ldots \ldots \ldots \\
& \text { ttabel }[(n-k) ; \alpha / 2] \\
& \beta_{i}: \text { koefisien regresi ke-i } \\
& S \beta_{i}: \text { standard error koefisien regresi ke-i }
\end{aligned}
$$

Selanjutnya pengujian multikolinearitas (Farrar and Glauber, 1967) dengan metode VIF (variance inflation factor) yang menurut Gujarati and Porter cit Rahim (2012) dirumuskan :

$$
V T F=\frac{1}{1-R_{j}^{2}}
$$

$\mathrm{R}_{j}^{2}$ diperoleh dari regresi auxilary antara variabel independen atau koefisien determinasi antara variabel bebas ke- dengan variabel bebas lainnya. Jika nilai VIF lebih kecil dari 10 maka tidak terdapat multikolinearitas. Lain halnya pengujian heterokedastisitas dengan park test (Park cit Rahim (2012) berikut :

$$
\begin{aligned}
\operatorname{Ln} \hat{e}_{i}^{2} & =\operatorname{Ln} \sigma^{2}+\beta \operatorname{Ln} X_{i}+v_{i} \\
& =a+\beta \operatorname{Ln} X_{i}+v_{i} \ldots
\end{aligned}
$$

Jika koefisien ( $\beta$ ) tidak signifikan, maka disimpulkan tidak terdapat heterokedastitas karena varian residualnya tidak tergantung dari variabel independen, sebaliknya jika $\beta$ signifikan maka mengandung unsur heterokedastitas karena besar kecilnya varian residual ditentukan oleh variabel independen.

\section{HASIL DAN PEMBAHASAN}

\section{a. Analisis Regeresi Linear Berganda}

Analisis uji prasyarat dalam penelitian ini yaitu mengunakan uji asumsi klasik sebagai salah satu syarat dalam mengunakan analisis regresi. Adapun pengujiannya dapat dibagi dalam beberapa tahap pengujian yaitu:

Berdasarkan hasil uji normalitas dengan grafik Histogran, pola distribusi mendekati normal, karena data mengikuti arah garis grafik histogramnya. Sehingga dapat disimpulkan bahwa asumsi normalitas telah terpenuhi dan layak dipakai untuk memprediksi kredit konsumsi berdasarkan variabel bebasnya. Normal Probability Plot, menunjukkan bahwa data menyebar disekitar garis diagonal dan mengikuti arah garis diagonal dan menujukkan pola distribusi normal, sehingga dapat disimpulkan bahwa asumsi normalitas telah terpenuhi dan layak dipakai untuk memprediksi kredit konsumsi berdasarkan variabel bebasnya.

Berdasarkan hasil uji multikolonieritas, diketahui nilai VIF untuk masing- masing variabel suku bunga, nilai tukar dan inflasi nilai VIF nya $<10$ dan nilai toleransinya $>0,10$ sehingga model dinyatakan tidak terjadi multikolonieritas. Sedangkan hasil uji heteroksedastisitas diperoleh hasil Scatterplot, terlihat titik-titik menyebar secara acak dan tidak membentuk suatu pola tertentu yang jelas, serta tersebar baik diatas maupun dibawah angka 0 pada sumbu Y. Hal ini berarti tidak terjadi heteroksedastisitas pada model regresi, sehingga model regresi layak dipakai untuk memprediksi pengaruh variabel berdasarkan masukan variabel independennya. 
Hasil uji autokorelasi menunjukkan bahwa nilai Durbin Waston menunjukkan nilai 1,880 $>1,767 \leq 5$ dengan demikian maka dapat disimpulkan bahwa koefisien bebas dari gangguan autokorelasi. Ringkasan hasil analisis regresi linear berganda pada penelitian ini dapat dilihat pada Tabel 1 berikut ini

Tabel. 1. Hasil Analisis Regresi Linear Berganda

\begin{tabular}{lccccc}
\hline Variabel Independen & $\begin{array}{c}\text { Tanda Harapan } \\
(\mathrm{T} . \mathrm{H})\end{array}$ & $\begin{array}{c}\text { Koefisien } \\
(\beta)\end{array}$ & t-hitung & Sig & VIF \\
\hline Suku Bunga & - & $-4,854$ & $-9,485$ & 0,000 & 1,240 \\
Nilai Tukar Rupiah & + & 1,358 & 4,879 & 0,003 & 1,229 \\
Inflasi & - &,- 139 & $-1,389$ & 0,214 & 1,017 \\
\hline Durbin Waston $(\mathrm{DW})$ & & & & 1,880 \\
\hline Konstanta & & & 19,246 \\
\hline F-hitung & & & 65,625 \\
\hline Adjusted $\mathrm{R}^{2}$ & & & 0,956 \\
\hline Sampel $(\mathrm{n})$ & & & 0,005 \\
\hline Taraf Signifikan $(\alpha)$
\end{tabular}

Sumber: Analisis data sekunder setelah diolah, Tahun 2017

Berdasarkan hasil olah data pada Tabel 1 di atas, diperoleh nilai koefisien determinasi yang disesuaikan yang disimbolkan dengan (Adjusted $\mathrm{R}^{2}$ ) sebesar 0.956 dengan kata lain hal ini menunjukkan bahwa besar persentase variasi permintaan kredit konsumsi yang bisa dijelaskan oleh variasi dari ketiga variabel bebas yaitu suku bunga, nilai tukar dan inflasi sebesar 95,6 persen sedangkan sisanya sebesar 4,4 persen dijelaskan oleh variabel-variabel lain di luar model penelitian.

Berdasarkan Tabel 1, dapat dilihat hasil koefisien regresi $(\beta)$ di atas, maka diperoleh persamaan regresi sebagai berikut :

$$
\mathrm{Ln}_{\mathrm{QdKKms}}=19.246+(-4.584 \mathrm{LnSBI})+1.358 \mathrm{LnNTR} p+(-0.139 \operatorname{Ln} I n f)+\mu \ldots
$$

Hasil dari persamaan regresi di atas dapat diinterpretasikan sebagai berikut:

Nilai koefisien $\beta_{0}$ sebesar 19.246 jika variabel suku bunga $\left(\mathrm{X}_{1}\right)$, nilai tukar $\left(\mathrm{X}_{2}\right)$,dan inflasi $\left(\mathrm{X}_{3}\right)$, konstan atau $\mathrm{X}=0$, maka maka kredit konsumsi naik sebesar 19.246. Nilai koefisien $\beta_{1}=-4.584$. Artinya di ketahui bahwa apabila suku bunga mengalami kenaikan sebesar 1 persen maka kredit konsumsi mengalami penurunan sebesar -4.584. Koefisien bernilai negatif artinya terjadi hubungan negatif antara suku bunga dan kredit karena semakin naik suku bunga maka kredit semakin menurun. Hasil ini sejalan dengan Hipotesis (tanda harapan) yang diajukan.

Nilai koefisien $\beta_{2}=1.358$ Artinya apabila nilai tukar mengalami kenaikan sebesar 1 Rupiah maka kredit konsumsi mengalami peningkatan sebesar 1.358 rupiah. Koefisien bernilai positif artinya terjadi hubungan positif antara nilai tukar dan kredit karena semakin naik nilai tukar (Apresiasi) maka kredit semakin meningkat. Hasil ini konsisten dengan hipotesis (tanda harapan) yang di ajukan.

Nilai koefisien $\beta_{3}=-0.139$ Artinya variabel inflasi mengalami kenaikan sebesar 1 persen maka kredit konsumsi mengalami penurunan sebesar -0.139 . Koefisien bernilai negatif artinya terjadi hubungan negatif antara inflasi dan kredit karena dengan naiknya inflasi maka kredit semakin menurun. Hasil ini sejalan dengan Hipotesis (tanda harapan) yang diajukan. 
Wardihan Sabar, dan Kuslin. Menakar Dampak Suku Bunga...

\section{b. Dampak Suku Bunga Terhadap Kredit Konsumsi}

Berdasarkan hasil penelitian diketahui bahwa suku bunga berpengaruh negatif dan signifikan terhadap permintaan kredit konsumsi di Sulawesi Selatan. Hasil penelitian ini tidak sejalan dengan temuan Wahab (2015) bahwa Suku Bunga tidak berpengaruh signifikan terhadap penyaluran kredit di bank-bank umum di Sulawesi Selatan. Temuan ini juga tidak konsisten dengan hasil temuan Tandris et al., (2014) bahwa Suku bunga berpengaruh negatif namun signifikan terhadap permintaan kredit pada perbankan di Kota Manado. Begitu pula dengan temuan Hutagalung dan Nasution (2013) menyatakan bahwa Suku bunga berpengaruh negatif namun signifikan terhadap permintaan kredit di Sumatera Utara. Pendapat yang sama dikemukakan oleh Pratama (2010) bahwa suku bunga Sertifikat Bank Indonesia (SBI) berpengaruh positif dan tidak signifikan terhadap penyaluran kredit perbankan.

Perubahan pada tingkat bunga riil akan menyababkan dua dampak yaitu income effect dan substitution effect. Income Effect yang terjadi yaitu perubahan konsumsi yang disebabkan oleh pergerakan kurva IC yang lebih tinggi pada barang normal, maka konsumen akan mendapat keuntungan selama dua periode. Dampak pendapatan ini akan membuat konsumen menginginkan lebih banyak konsumsi dalam dua periode. Substitution effect yang tejadi adalah perubahan konsumsi yang disebabkan oleh perubahan harga relatif konsumsi pada kedua periode. Pada saat tingkat suku bunga naik, $C 2$ akan menjadi lebih murah dibandingkan dengan C1. Hal ini menunjukkan bahwa tingkat bunga riil diterima dengan menabung akan lebih tinggi, maka konsumen harus mengurangi $C 1$ untuk mendapatkan satu unit tambahan dari C2. Hal ini mengakibatkan konsumsi pada periode kedua akan menjadi lebih banyak dan konsumsi pada periode pertama lebih sedikit. Pada kasus konsumen sebagai peminjam, income effect memiliki nilai yang negatif karena konsumsi yang dilakukan oleh konsumen melebihi pendapatan yang ia miliki. Konsumen akan meminjam kepada bank untuk mendapatkan uang lebih yang digunakan untuk mengkonsumsi. Akibatnya konsumen akan mengkonsumsi lebih sedikit untuk periode di masa depan (Mankiw cit Agustin, 2012).

Menurut Nopirin (1992) tingkat bunga memiliki fungsi dalam perekonomian yaitu alokasi faktor produksi untuk menghasilkan barang dan jasa yang dipakai sekarang dan di kemudian hari. Sementara meurut Haryono et al., (2000) menyatakan bahwa suku bunga jangka pendek berfungsi sebagai target operasional kebijakan moneter yang diharapkan dapat mempengaruhi agregat demand, untuk selanjutnya mempengaruhi pencapaian sasaran inflasi. Selain itu, perubahan suku bunga juga dapat melewati jalur nilai tukar dan ekspektasi masyarakat sebelum akhirnya mempengaruhi inflasi.

Fenomena yang terjadi pada masyarakat sekarang, diketahui bahwa pengeluaran untuk konsumsi memiliki jumlah yang besar karena kebutuhan masyarakat yang sifatnya tidak terbatas. Hal inilah yang menjadi faktor pendorong bagi masyarakat untuk mengambil kredit. Beberapa alasan yang mendasari tingkat pengeluran konsumsi masyarakat atau rumah tangga tinggi karena pengeluran konsumsi masyarakat memiliki posisi terbesar dalam total pengeluaran agregat dan didukung pula dengan perkembangan masyarakat yang pesat mengakibatkan perilaku-perilaku masyarakat juga berubah pesat serta didukung dengan zaman sekarang dimana hidup selalu ingin yang serba modern dan instan, hal inilah yang dapat menyebabkan peningkatan pengeluaran konsumsi masyarakat.

Perkembangan suku bunga dalam sepuluh tahun terakhir menunjukkan persentase yang beragam, meski tergolong cukup tinggi namun dalam dua tahun terakhir secara berturutturut suku bunga mengalami penurunan sehingga semakin mendorong masyarakat untuk mengambil kredit karena mengingat kecilnya bunga yang akan dibayar pada saat tingkat suku bunga menurun.

Menurut Mochtar (2003), diperlukan adanya pengendalian suku bunga SBI agar tidak terlalu tinggi mengingat bila tetap dipertahankan tinggi akan memberikan dampak ke periode depan bagi peningkatan kembaliinflasi. Lebih lanjut bila suku bunga SBI tersebut tetap 
dipertahankan dalam kisaran tinggi sehingga selanjutnya akan dapat semakin meningkatkan biaya dalam pembayaran bunga SBI (dan juga bagi potensi peningkatan kembali uang beredar) maka dikhawatirkan pada satu waktu akan memiliki dampak balik yang kurang baik bagi kredibilitas dan komitmen Bank Indonesia dalam menjalankan kebijakan moneter. Bila rumah tangga representatif memiliki ekspektasi rasional yang baik tentang kemungkinan terjadinya time inconsistency dari kebijakan moneter ini maka selanjutnya dikhawartirkan pada satu waktu akan semakin mempersulit pengendalian inflasi oleh Bank Indonesia.

\section{c. Dampak Nilai Tukar Terhadap Kredit Konsumsi}

Berdasarkan hasil penelitian diketahui bahwa nilai tukar berpengaruh positif dan signifikan tehadap kredit konsumsi di Sulawesi Selatan. Hasil penelitian ini menunjukkan bahwa semakin meningkat nilai tukar rupiah terhadap dollar (apresiasi), maka permintaan kredit konsumsi akan meningkat. Hasil penelitian ini tidak sejalan dengan temuan Putri (2012) bahwa nilai tukar (kurs) tidak menunjukkan pengaruh signifikan terhadap Penyaluran Kredit di Perbankan yang dilihat dari nilai Loan to Deposit Ratio (LDR). Hasil temuan ini Konsisten dengan temuan Sidiq (2005) bahwa nilai tukar berpengaruh signifikan positif terhadap permintaan uang riil baik untuk M1 dan M2. Sementara temuan Hutagalung dan Nasution (2013) menyatakan bahwa Kurs rupiah terhadap dollar mempunyai pengaruh negatif terhadap permintaan kredit konsumsi di Sumatera Utara. Hasil penelitian ini konsisten dengan hasil penelitian Junaidi (2006), yang menemukan bahwa semakin tinggi nilai tukar rupiah (rupiah terapresiasi), maka permintaan kredit akan semakin meningkat.

Kurs mata uang menunjukkan harga mata uang apabila ditukarkan dengan mata uang lain. Penentuan nilai kurs mata uang suatu negara dengan mata uang negara lain ditentukan sebagai mana halnya barang yaitu oleh permintaan dan penawaran mata uang yang bersangkutan. Hukum ini juga berlaku untuk kurs rupiah, jika demand akan rupiah lebih banyak daripada suplainya maka kurs rupiah ini akan terapresiasi, demikian pula sebaliknya. Apresiasi atau depresiasi akan terjadi apabila negara menganut kebijakan nilai tukar mengambang bebas (free floating exchange rate) sehingga nilai tukar akan ditentukan oleh mekanisme pasar (Kuncoro cit Witjaksono, 2010).

Menurut Atmadja (2004) dalam penelitiannya menyatakan bahwa Pergerakan nilai tukar mata uang rupiah di Indonesia ternyata bukan merupakan dominasi faktor ekonomi saja, maka tanggung jawab pengendalian nilai tukar bukan hanya berada pada pemegang otoritas moneter ataupun instansi yang bergerak dalam sektor ekonomi saja, tetapi juga merupakan tanggung jawab dari instansi lainnya (yang beraktivitas di luar bidang ekonomi) dalam menciptakan kondisi yang dapat menunjang proses pencapaian nilai tukar mata uang rupiah terhadap dolar Amerika seperti yang telah ditargetkan. Untuk itu, maka perlu adanya pembagian tugas yang jelas dan terarah antar lembaga negara dengan kebijakan-kebijakan pemerintah yang komprohensif, baik di bidang ekonomi maupun di bidang non ekonomi, hingga terciptanya sinergi. Lebih lanjut, kebijakan perubahan suku bunga SBI yang kerapkali digunakan oleh bank sentral dengan maksud mengendalikan nilai tukar rupiah terhadap dolar Amerika ternyata tidak mampu secara signifikan mempengaruhi perubahan nilai tukar rupiah. Hal ini secara ekonomi antara lain dapat disebabkan, karena adanya kebijakan bank sentral Amerika yang kadangkala juga menggunakan instrumen yang sama (dengan fedfund-nya) dalam mempertahankan nilai tukar dolar Amerika terhadap mata uang asing lainnya, dan karena tingginya tingkat inflasi yang terjadi di Indonesia.

Kurs mata uang asing mengalami perubahan nilai yang terus menerus dan relatif tidak stabil. Kecenderungan nilai tukar rupiah yang saat ini terus terdepresiasi akibat kebijakan kenaikan suku bunga The Federal Reserve (The Fed), dan membaiknya kondisi ekonomi Amerika Serikat meningkatkan kepercayaan investor untuk menanamkan modalnya kembali. Hal ini 
menyebabkan kecenderungan kenaikan harga secara umum terhadap barang-barang domestik dan utamanya terhadap barang-barang impor, serta melemahnya daya beli maysarakat, dan respon positif terhadap kenaikan suku sunga SBI. Dampaknya terhadap permintaan kredit konsumsi khususnya untuk kredit konsumsi barang-barang impor akan cenderung menurun. Perubahan nilai ini dapat terjadi karena adanya perubahan permintaan dan penawaran atas suatu nilai mata uang asing pada masing-masing pasar pertukaran valuta dari waktu ke waktu. Sedangkan perubahan permintaan dan penawaran itu sendiri dipengaruhi oleh adanya kenaikan relatif tingkat bunga baik secara bersama-sama maupun sendiri-sendiri terhadap negara.

\section{d. Dampak Inflasi Terhadap Kredit Konsumsi}

Berdasarkan hasil penelitian diketahui bahwa inflasi tidak berpengaruh signifikan terhadap permintaan kredit konsumsi di Sulawesi Selatan. Hasi temuan ini sejalan dengan temuan Putri (2012) bahwa Inflasi tidak menunjukkan pengaruh signifikan terhadap Penyaluran Kredit di Perbankan yang dilihat dari nilai Loan to Deposit Ratio (LDR). Begitu pula dengan temuan Wahab (2015) bahwa Inflasi tidak berpengaruh signifikan terhadap penyaluran kredit di bank-bank umum di Sulawesi Selatan.

Inflasi merupakan suatu proses meningkatnya harga-harga secara umum dan terusmenerus berkaitan dengan mekanisme pasar yang disebabkan berbagai faktor, salah satunya adalah konsumsi masyarakat yang meningkat. Dalam inflasi, tinggi rendahnya harga belum dianggap sebagai masalah artinya tingkat harga yang tinggi belum tentu menentukan inflasi tetapi lebih kepada dampak yang akan ditimbulkan inflasi.

Pernyataan diatas sejalan dengan pandangan Edmund (1973), bahwa dalam ekonomi, inflasi adalah peningkatan berkelanjutan dalam tingkat harga barang dan jasa secara umum dalam suatu ekonomi selama periode waktu. Ketika tingkat harga naik, setiap unit mata uang membeli lebih sedikit barang dan jasa. Akibatnya, inflasi mencerminkan penurunan daya beli per unit uang, hilangnya nilai riil dalam medium pertukaran, dan unit produksi dalam perekonomian. Ukuran utama inflasi harga adalah tingkat inflasi, perubahan persentase tahunan dalam indeks harga umum, biasanya indeks harga konsumen, dari waktu ke waktu. Kebalikan dari inflasi adalah deflasi. Inflasi mempengaruhi ekonomi dengan berbagai cara positif dan negatif. Efek negatif dari inflasi termasuk peningkatan biaya peluang memegang uang, ketidakpastian atas inflasi masa depan yang dapat menghambat investasi dan tabungan, dan jika inflasi cukup cepat, kekurangan barang karena konsumen mulai menimbun karena kekhawatiran bahwa harga akan meningkat di masa depan. Efek positif termasuk mengurangi beban nyata utang publik dan swasta, menjaga suku bunga nominal di atas nol sehingga bank sentral dapat menyesuaikan suku bunga untuk menstabilkan ekonomi, dan mengurangi pengangguran karena kekakuan upah nominal.

Teori kuantitas menyatakan bahwa terjadinya inflasi hanya disebabkan oleh satu faktor yaitu akibat adanya kenaikan jumlah uang beredar (JUB). Jika jumlah uang beredar meningkat maka akan terjadi inflasi yang sifatnya negatif karena dapat menyebabkan harga-harga barang juga ikut meningkat. Berbeda halnya dengan teori Irving Fisher, Keynes mengatakan bahwa inflasi terjadi karena masyarakat ingin hidup diluar batas kemampuan ekonominya dengan demikian permintaan masyarakat akan barang-barang melebihi jumlah barang yang tersedia. hal ini terjadi karena masyarakat mengetahui dan menjadikan keinginan tersebut dalam bentuk permintaan yang efektif terhadap barang. Dengan kata lain, masyarakat berhasil memperoleh dana tambahan diluar batas kemampuan ekonominya sehingga golongan masyarakat ini bisa memperoleh barang dengan jumlah yang lebih besar dari pada seharusnya.

Bila jumlah permintaan barang meningkat, pada tingkat harga berlaku melebihi jumlah maksimum dari barang-barang yang bisa dihasilkan oleh masyarakat, maka inflationary gap akan timbul. Keadaan ini menyebabkan harga- harga naik dan berarti rencana pembelian barang tidak dapat terpenuhi. Pada periode selanjutnya, masyarakat berusaha untuk 
memperoleh dana yang lebih besar lagi baik dari kredit pada bank maupun permintaan kenaikan gaji. Proses inflasi tetap akan berlangsung selama jumlah permintaan efektif dari semua golongan masyarakat melebihi output yang bisa dihasilkan masyarakat.

Para ekonom umumnya percaya bahwa tingkat inflasi, dan hiperinflasi yang tinggi disebabkan oleh pertumbuhan jumlah uang beredar yang berlebihan. Namun, pertumbuhan pasokan uang tidak selalu menyebabkan inflasi. Beberapa ekonom mempertahankan bahwa di bawah kondisi jebakan likuiditas, suntikan moneter besar seperti "mendorong pada string". Pandangan tentang faktor-faktor yang menentukan tingkat inflasi rendah hingga sedang lebih bervariasi. Inflasi rendah atau sedang dapat dikaitkan dengan fluktuasi permintaan nyata untuk barang dan jasa, atau perubahan dalam persediaan yang tersedia seperti selama kelangkaan. Namun, pandangan konsensus adalah bahwa periode inflasi yang berkelanjutan panjang disebabkan oleh pasokan uang tumbuh lebih cepat daripada tingkat pertumbuhan ekonomi. Hari ini, sebagian besar ekonom menyukai tingkat inflasi yang rendah dan stabil. Rendah (lawan nol atau negatif) inflasi mengurangi keparahan resesi ekonomi dengan memungkinkan pasar tenaga kerja untuk menyesuaikan lebih cepat dalam penurunan, dan mengurangi risiko bahwa perangkap likuiditas mencegah kebijakan moneter dari menstabilkan perekonomian. Tugas menjaga tingkat inflasi rendah dan stabil biasanya diberikan kepada otoritas moneter. Umumnya, otoritas moneter ini adalah bank sentral yang mengendalikan kebijakan moneter melalui pengaturan suku bunga, melalui operasi pasar terbuka, dan melalui pengaturan persyaratan cadangan perbankan (Edmund, 1973).

Meskipun dari temuan ini menunjukkan bahwa inflasi tidak berpengaruh signifikan terhadap permintaan kredit konsumsi di Sulawesi Selatan, namun apabila inflasi tinggi kemungkinan besar masyarakat tidak akan mengambil kredit karena mengingat besarnya bunga yang akan dibayar, dan sebaliknya apabila tingkat inflasi rendah maka, kemungkinan besar masyarakat cenderung untuk mengambil kredit karena tingkat bunga yang akan dibayar masih pada batas yang dapat dipenuhi oleh masyarakat pada umumnya.

\section{PENUTUP}

Meningkatnya penyaluran kredit utamanya kredit konsumsi, telah memberikan dampak positif terhadap peningkatan aktivitas ekonomi di Sulawesi Selatan. Kredit merupakan aktivitas bank yang paling dominan dari seluruh kegiatan aktivitas operasional bank. Bahkan sebagian besar aset bank berasal dari kredit. Faktor-faktor fundamental yang mempengaruhi tingkat permintaan kredit konsumsi, seperti Suku bunga berpengaruh negatif terhadap permintaan kredit konsumsi di Sulawesi Selatan. Kecenderungan masyarakat secara umum pada saat suku bunga rendah akan cenderung mengambil kredit mengingat kecilnya bunga yang akan dibayar. Faktor lainnya seperti nilai tukar rupiah memberi berpengaruh positif terhadap permintaan kredit konsumsi di Sulawesi Selatan periode 2007-2016. Sementara Inflasi tidak berpengaruh terhadap permintaan kredit konsumsi di Sulawesi Selatan periode 2007-2016.

Kecenderungan permintaan kredit konsumsi perlu mendapatkan perhatian serius oleh stakeholder terkait, mengingat peningkatan aktivitas ini memberi respon positif terhadap laju inflasi yang terus mengalami peningkatan. Inflasi tentunya menjadi salah satu bagian dari tugas pokok Bank Indonesia melalui instrumen moneter, dan Tim Pengendali Inflasi Daerah (TPID) Sulawesi Selatan, sebab faktor ini memiliki hubungan secara langsung terhadap paritas daya beli masyarakat. Diperlukan langkah antisipatif untuk menekan laju depresiasi rupiah terhadap dollar AS, agar dapat menangkal efek negatif dari kecenderungan kenaikan harga secara umum terhadap barang-barang domestik, dan utamanya terhadap barang-barang impor. 
Wardihan Sabar, dan Kuslin. Menakar Dampak Suku Bunga...

\section{DAFTAR PUSTAKA}

Agustin, Niken, dan Hadi Sasana. (2012). Analisis Konsumsi Rumah Tangga Petani Padi dan Palawija di Kabupaten Demak (Doctoral dissertation, Fakultas Ekonomika dan Bisnis).

Atmadja, A. Surja. (2004). Analisa pergerakan nilai tukar rupiah terhadap dolar Amerika Setelah Diterapkannya kebijakan sistem nilai tukar mengambang bebas di Indonesia. Jurnal Akuntansi dan keuangan, 4(1), 69-78.

Carroll, Christopher D, (2001). "A theory of the consumption function, with and without liquidity constraints." Journal of Economic perspectives 15.3: 23-45.

Clara, Safitri, Dawali. Dkk, (2014). Analisis Estimasi Permintaan Dan Penawaran Kredit Konsumsi Bank Umum Di Provinsi Sulawesi Utara Periode 2007-2013. Fakultas Ekonomi dan Bisnis, Jurusan IlmuEkonomi Pembangunan, Universitas Sam Ratulangi, Manado.

Duesenberry, James. S, (1949). Income, Saving, And Consumers Bahavior Theory. Hardvard University Press.

David Nachmias \& Chava Nachmias, (1987). Research Methods in the Social Sciences, Third Edition, New York: St. Martin's Press, page. 10-15

Friedman, Milton, (1957). A theory of Consumption Function .Princeton University Press.

Friedman, Milton, (2017)."Quantity theory of money." The new Palgrave dictionary of economics : $1-31$.

Fisher, Irving, (1912). The Purchasing Power Of Money. New York: Cossimoclassics.

Godley, Wynne, (1999). "Money and credit in a Keynesian model of income determination." Cambridge journal of economics 23.4 393-411.

Glenn, Hubbard. R, (2006). Money, The Financial System, And The Economy.

Harefa, Albert. N, (2010). Analisis Faktor-Faktor Yang Mempengarubi Permintaan Kredit Konsumsi Pada Bank Umum Di Indonesia (Pendekatan Error Correction Model).

Haryono, E., Nugroho, W. A., \& Pratomo, W. (2000). Mekanisme pengendalian moneter dengan inflasi sebagai sasaran tunggal. Buletin Ekonomi Moneter dan Perbankan, 2(4), 68122.

Hutagalung, Paulina Putri A., and Inggrita Gusti Sari Nasution, (2013). "Analisis Elastisitas Permintaan Terhadap Kredit Konsumsi di Sumatera Utara." Jumal Ekonomi dan Keuangan 1.(2).

Keynes, Jhon, Maynard, (1969). The General Theory of Employment, Interest and Money, Brace and World, Harcourt.

Koivu, Tuuli, (2009). Has the Chinese economy become more sensitive to interest rates? Studying credit demand in China. China Economic Review, 20(3), 455-470.

Leedy, Paul D., and Jeanne Ellis Ormrod, (2005). Practical Research. Pearson Custom, 
Lipsey, Richard G. "4A IS-LM, Keynesianism, and the new classicism." Macroeconomics and the Real World: Volume 2: Keynesian Economics, Unemployment, and Policy (2000): 57.

Miraza, dan Bachtiar Hasan (2006). Perjalanan Motener dan Perkembangan Perbankan.

Mishkin, Frederick S, (2008). The Economics of Money, Banking, and Financial Market, eight edition. Canada: Pearson Education.

Miller, Roger Le Roy dan Roger E. Meiners, (2001). Teori Ekonomi Intermediate, edisi ketiga. Jakarta: Raja GrafindoPersada.

Mochtar, Firman. (2003). SBI, T-Bills dan Pengendalian Inflasi. Buletin Ekonomi Moneter dan Perbankan, 6(2), 53-73.

Nachmias, David, and Chava Nachmias, (1987). "Research methods in the social sciences. New York: St."

Phelps, Edmund S, (1973). "Inflation in the theory of public finance." The Swedish Journal of Economics : $67-82$.

Pratama, Billy Arma, (2010). Analisis faktor-faktor yang mempengarubi kebijakan penyaluran kredit perbankan (Studi pada Bank Umum di Indonesia Periode Tabun 2005-2009). Diss. Universitas Diponegoro.

Putri, Dwi Anggraeni Sri Hadi, Mochammad Chabachib, dan Irene Demi Pengestuti, (2012) Analisis Pengaruh Tingkat Suku Bunga SBI, DPK, Inflasi, Kredit Non Lancar, dan Nilai Tukar Terbadap LDR pada Bank Umum di Indonesia Tabun 2006-2009. Diss. Diponegoro University.

Rahim, Abd, (2012). "Model Ekonometrika Perikanan Tangkap."

Samuelson, P. A., \& Nordhaus, W. D, (1996). Makro Ekonomi. Jakarta: Erlangga.

Sidiq, Sahabudin, (2005). "Stabilitas Permintaan Uang di Indonesia Sebelum dan Sesudah Perubahan Sistem Nilai Tukar." Economic Journal of Emerging Markets 10.(1)

Tandris, Raimond, Parengkuan Tommy, and Sri Murni, (2014). "Suku Bunga, Inflasi dan Nilai Tukar Pengaruhnya Terhadap Permintaan Kredit Perbankan di Kota Manado." Jurnal EMBA: Jurnal Riset Ekonomi, Manajemen, Bisnis dan Akuntansi 2.1

Wahab, Abdul, (2015). Pengaruh PDRB, Inflasi, Suku Bunga Bank Indonesia dan Dana Pihak Ketiga Terhadap Penyaluran Kredit Pada Bank-Bank Umum Di Sulawesi Selatan. EcceS (Economics, Social, and Development Studies), 2(1), 1-25.

Witjaksono, Ardian Agung, (2010). Analisis Pengarub Tingkat Suku Bunga SBI, Harga Minyak Dunia, Harga Emas Dunia, Kurs Rupiah, Indeks Nikkei 225, dan Indeks Dow Jones terbadap IHSG (studi kasus pada IHSG di BEI selama periode 2000-2009). Diss. Universitas Diponegoro,. 